\title{
Natural Resources: Extractions, Depletions, Protections and Sustainable Managements
}

\author{
M. Aminur Rahman \\ World Fisheries University Pilot Programme, Pukyong National University (PKNU), \\ 45 Yongso-ro, Nam-gu, Busan 48513, South Korea
}

\begin{abstract}
Natural resources are naturally occurring substances that are considered valuable in their relatively unmodified form. A commodity is generally considered a natural resource when the primary activities associated with it are extraction and purification, as opposed to creation. Thus, mining, petroleum extraction, fishing, and forestry are generally considered natural-resource industries. Natural resources are often classified into renewable and non-renewable resources. Renewable resources are generally living resources (fish, coffee, and forests etc.), which can restock (renew) themselves if they are not overharvested. Renewable resources can restock themselves and be used indefinitely if they are used sustainably. Non-living renewable natural resources include soil, as well as water, wind, tides and solar radiation - compare with renewable energy. Resources can also be classified on the basis of their origin as biotic and abiotic. Biotic resources are derived from animals and plants (i.e., the living world). Abiotic resouces are derived from the non-living world. e.g. land, water, and air. Mineral and power resources are also abiotic resources some are derived from nature. Both extraction of the basic resource and refining it into a purer, directly usable form, (e.g., metals, refined oils) are generally considered natural-resource activities, even though the latter may not necessarily occur near the former. Natural resources are natural capital converted to commodity inputs to infrastructural capital processes. They include soil, timber, oil, minerals, and other goods taken more or less as they are from the Earth. A nation's natural resources often determine its wealth and status in the world economic system, by determining its political influence. Developed nations are those which are less dependent on natural resources for wealth, due to their greater reliance on infrastructural capital for production. In recent years, the depletion of natural capital and attempts to move to sustainable development has been a major focus of development agencies. This is of particular concern in rainforest regions, which hold most of the Earth's natural biodiversity - irreplaceable genetic natural capital. Conservation of natural resources is the major focus of Natural Capitalism, environmentalism, the ecology movement, and Green Parties. Some view this depletion as a major source of social unrest and conflicts in developing nations.
\end{abstract}

Keywords — Natural resources, extractions, depletions, protection, management

\section{Introduction}

The Natural resources are materials which occur naturally and can be exploited/used by human beings. This includes all valued characteristics such as magnetic, gravitational, and electrical properties and forces. On earth it includes: sunlight, atmosphere, water, land (includes all minerals) along with all vegetation and animal life that naturally subsists upon or within the heretofore identified characteristics and substances [1, 2, 3, 4]. Natural resources may be further classified in different ways. They are materials and components that can be found within the environment. Every man-made product is composed of natural resources. A natural resource may exist as a separate entity such as fresh water, air, as well as a living organism such as a fish, or it may exist in an alternate form that must be processed to obtain the resource such as metal ores, petroleum, and most energy forms. Some examples of natural resources and the ways we can use them are: 


\begin{tabular}{|l|l|}
\hline Natural Resource & \\
\hline Air & Wind energy, tires \\
\hline Animals & Foods (milk, cheese, steak, bacon) and clothing (wool sweaters, silk shirts, leather belts) \\
\hline Coal & Electricity \\
\hline Minerals & Coins, wire, steel, aluminum cans, jewelry \\
\hline Natural gas & Electricity, heating \\
\hline Oil & Electricity, fuel for cars and airplanes, plastic \\
\hline Plants & Wood, paper, cotton clothing, fruits, vegetables \\
\hline Sunlight & Solar power, photosynthesis \\
\hline Water & Hydroelectric energy, drinking, cleaning \\
\hline
\end{tabular}

Much debates have been remaining worldwide over natural resource allocations, this is particularly true during periods of increasing scarcity and shortages but also because the exportation of natural resources is the basis for many economies, particularly for developed countries. A variety of natural resources such as sunlight and air can be found everywhere, and are known as ubiquitous resources. However, most resources only occur in small sporadic areas, and are referred to as localized resources. There are very few resources that are considered inexhaustible - these are solar radiation, geothermal energy, and air. The vast majority of resources are theoretically exhaustible, which means they have a finite quantity and can be depleted if managed improperly.

\section{Types and Classifications of Natural Resources}

Various methods are involved in categorizing natural resources, these include source of origin, stage of development and by their renewability.

On the basis of origin, natural resources may be divided into two types:

- Biotic: Biotic resources are obtained from the biosphere, such as forests and animals, and the materials that can be obtained from them. Fossil fuels such as coal and petroleum are also included in this category because they are formed from decayed organic matter.

- Abiotic: Abiotic resources are those that come from non-living, non-organic material. Examples of abiotic resources include land, fresh water, air and heavy metals including ores such as gold, iron, copper, silver, etc. Considering their stage of development, natural resources may be referred to in the following ways:

- Potential resources: Potential resources are those that exist in a region and may be used in the future. For example, petroleum occurs with sedimentary rocks in various regions, but until the time it is actually drilled out and put into use, it remains a potential resource.

Actual resources: Actual resources are those that have been surveyed, their quantity and quality determined and are being used in present times. The development of an actual resource, such as wood processing depends upon the technology available and the cost involved.

- $\quad$ Reserve resources: The part of an actual resource which can be developed profitably in the future is called a reserve resource.

- Stock resources: Stock resources are those that have been surveyed but cannot be used by organisms due to lack of technology. For example: hydrogen.

Renewability is a very popular topic and many natural resources can be categorized as either renewable or nonrenewable:

Renewable resources: Renewable resources can be replenished naturally. Some of these resources, like sunlight, air, wind, water, etc., are continuously available and their quantity is not noticeably affected by human consumption. Though many renewable resources do not have such a rapid recovery rate, these resources are susceptible to depletion by over-use. Resources from a human use perspective are classified as renewable so long as the rate of replenishment/recovery exceeds that of the rate of consumption. 
Non-renewable resources: Non-renewable resources either form slowly or do not naturally form in the environment. Minerals are the most common resource included in this category. By the human perspective, resources are non-renewable when their rate of consumption exceeds the rate of replenishment; a good example of this are fossil fuels, which are in this category because their rate of formation is extremely slow, meaning they are considered non-renewable. Some resources actually naturally deplete in amount without human interference, the most notable of these being radio-active elements such as uranium, which naturally decay into heavy metals. Of these, the metallic minerals can be re-used by recycling them [5], but coal and petroleum cannot be recycled [6].

\section{Resource Extraction}

Resource extraction involves any activity that withdraws resources from nature. This can range in scale from the traditional use of preindustrial societies, to global industry. Extractive industries are, along with agriculture, the basis of the primary sector of the economy. Extraction produces raw material which is then processed to add value. Examples of extractive industries are hunting, trapping, mining, oil and gas drilling, and forestry. Natural resources can add substantial amounts to a country's wealth [7], however a sudden inflow of money caused by a resource boom can create social problems including inflation harming other industries and corruption, leading to inequality and underdevelopment.

Extractive industries represent a large growing activity in many less-developed countries but the wealth generated does not always lead to sustainable and inclusive growth. Extractive industry businesses often are assumed to be interested only in maximizing their short-term value, implying that less-developed countries are vulnerable to powerful corporations. Alternatively, host governments are often assumed to be only maximizing immediate revenue. Researchers argue there are areas of common interest where development goals and business cross. These present opportunities for international governmental agencies to engage with the private sector and host governments through revenue management and expenditure accountability, infrastructure development, employment creation, skills and enterprise development and impacts on children, especially girls and women [8].

\section{Resource Depletion}

In recent years, the depletion of natural resources has become a major focus of governments and organizations such as the United Nations (UN). This is evident in the UN's Agenda 21 Section Two, which outlines the necessary steps to be taken by countries to sustain their natural resources [9]. The depletion of natural resources is considered to be a sustainable development issue [10]. The term sustainable development has many interpretations, most notably the Brundtland Commission's 'to ensure that it meets the needs of the present without compromising the ability of future generations to meet their own needs' [11], however in broad terms it is balancing the needs of the planet's people and species now and in the future [9]. In regards to natural resources, depletion is of concern for sustainable development as it has the ability to degrade current environments[12] and potential to impact the needs of future generations [10]. The conservation of natural resources is the fundamental problem. Unless we solve that problem, it will avail us little to solve all others [13].

Depletion of natural resources is associated with social inequity. Considering most biodiversity are located in developing countries [14], depletion of this resource could result in losses of ecosystem services for these countries [15]. Some view this depletion as a major source of social unrest and conflicts in developing nations [16].

At present, with it being the year of the forest, there is particular concern for rainforest regions which hold most of the Earth's biodiversity [17]. According to Nelson [18], deforestation and degradation affect $8.5 \%$ of the world's forests with $30 \%$ of the Earth's surface already cropped. If we consider that $80 \%$ of people rely on 
medicines obtained from plants and $3 / 4$ of the world's prescription medicines have ingredients taken from plants [15], loss of the world's rainforests could result in a loss of finding more potential lifesaving medicines [19].

The depletion of natural resources is caused by 'direct drivers of change' such as mining, petroleum extraction, fishing and forestry as well as 'indirect drivers of change' such as demography, economy, society, politics and technology [18]. The current practice of Agriculture is another factor causing depletion of natural resources. For example, the depletion of nutrients in the soil due to excessive use of nitrogen [18] and desertification [9]. The depletion of natural resources is a continuing concern for society. This is seen in the cited quote given by Theodore Roosevelt, a well-known conservationist and former United States president, who was opposed to unregulated natural resource extraction [13].

\section{Resource Protection}

In 1982, the UN developed the World Charter for Nature, which recognized the need to protect nature from further depletion due to human activity. It states that measures need to be taken at all societal levels, from international to individual, to protect nature. It outlines the need for sustainable use of natural resources and suggests that the protection of resources should be incorporated into national and international systems of law [20]. To look at the importance of protecting natural resources further, the World Ethic of Sustainability, developed by the IUCN, WWF and the UNEP in 1990 [21], set out eight values for sustainability, including the need to protect natural resources from depletion. Since the development of these documents, many measures have been taken to protect natural resources including establishment of the scientific field and practice of conservation biology and habitat conservation, respectively.

Conservation biology is the scientific study of the nature and status of Earth's biodiversity with the aim of protecting species, their habitats, and ecosystems from excessive rates of extinction [22, 23]. It is an interdisciplinary subject drawing on science, economics and the practice of natural resource management [2427]. Habitat conservation is a land management practice that seeks to conserve, protect and restore, habitat areas for wild plants and animals, especially conservation reliant species, and prevent their extinction, fragmentation or reduction in range [28].

\section{Resource Management}

Natural resource management is a discipline in the management of natural resources such as land, water, soil, plants and animals, with a particular focus on how management affects the quality of life for both present and future generations. Hence sustainable development can be followed where there is a judicial use of resources which compromises the needs of the present generations as well as the future generations. Management of natural resources involves identifying who has the right to use the resources and who does not for defining the boundaries of the resource [29]. The resources are managed by the users according to the rules governing of when and how the resource is used depending on local condition [30].

A successful management of natural resources should engage the community because of the nature of the shared resources the individuals who are affected by the rules can participate in setting or changing them [29]. The users have rights to devise their own management institutions and plans under the recognition by the government. The right to resources includes land, water, fisheries and pastoral rights [30]. The users or parties accountable to the users have to actively monitor and ensure the utilization of the resource compliance with the rules and to impose penalty on those peoples who violates the rules [29]. These conflicts are resolved in a quick and low cost manner by the local institution according to the seriousness and context of the offence [30]. The global science-based platform to discuss natural resources management is the World Resources Forum, based in Switzerland. 
Natural resource management issues are inherently complex. They involve the ecological cycles, hydrological cycles, climate, animals, plants and geography, etc. All these are dynamic and inter-related. A change in one of them may have far reaching and/or long term impacts which may even be irreversible. In addition to the natural systems, natural resource management also has to manage various stakeholders and their interests, policies, politics, geographical boundaries, economic implications and the list goes on. It is very difficult to satisfy all aspects at the same time. This results in conflicting situations. After the United Nations Conference for the Environment and Development (UNCED) held in Rio de Janeiro in 1992, most nations subscribed to new principles for the integrated management of land, water, and forests. Although program names vary from nation to nation, all express similar aims. In order to have a sustainable environment, understanding and using appropriate management strategies is important.

\section{References}

[1] Natural resources - definition of natural resources in English. 2014. Oxford Dictionaries. Retrieved on 12 December, 2016.

[2] Definition of natural resource - Merriam-Webster's Student Dictionary. 2012. Wordcentral.com. Retrieved on 12 December, 2016.

[3] What is Natural Resources? Definition and meaning. 2012. Investorwords.com. Retrieved on 12 December, 2016.

[4] Natural resource dictionary definition. 2012. Yourdictionary.com. Retrieved on 12 December, 2016.

[5] Earth's natural wealth: an audit. 2007. Science.org.au. May 23, 2007.

[6] Peak Everything? 2010. Reason.com. April 27, 2010.

[7] EnviroStats: Canada's natural resource wealth at a glance. 2014. Statcan.gc.ca. Retrieved on 31 May, 2014.

[8] Dietsche, E., Dodd, S., Haglund, D., Henstridge, M., Jakobsen, M., Sindou, E. and Slaven, C. 2016. Extractive industries, development and the role of donors. Economic and Private Sector Professional Evidence and Applied Knowledge Services. Partberplatform.org. Retrieved on 12 December, 2016.

[9] UN 2002 Earth Summit Agenda 21. 2011. The United Nations programme for action from Rio: Section Two Conservation and Management of Resources for Development, United Nations, Rio. Un.org. Retrieved on 12 December, 2016.

[10] Schilling, M. and Chiang, L. 2011. The effect of natural resources on sustainable development policy: The approach of non-sustainable externalities. Energy Policy, 39: 990-998.

https://doi.org/10.1016/j.enpol.2010.11.030

[11] UN 1987 Report of the World Commission on Environment and Development: Our Common Future. 2011. UN Documents: Gathering a body of global agreements. Un.org. Retrieved on 12 December, 2016.

[12] Salvati, L. and Marco, Z. 2008. Natural resource depletion and economic performance of local districts: suggestions from a within-country analysis. Journal of Sustainable Development and World Ecology, 15(6): 518-523. https://doi.org/10.1080/13504500809469847

[13] Roosevelt, T. 1907. Address to the Deep Waterway Convention Memphis, TN, October 4, 1907.

[14] UNESCO and UNEP. 2002. Cultural Diversity and Biodiversity for Sustainable Development, World Summit on Sustainable Development, Johannesburg.

[15] Nellemann, C. and Corcoran, E. 2010. Dead Planet, Living Planet- Biodiversity and Ecosystem Restoration for Sustainable Development: A Rapid Response Assessment. United Nations Environment Program, GRID-Arendal.

[16] Von Braun, J. 2005 Depletion of Natural Resources - Implications for Development: An assessment by experts Berne. Inforesources Trends, Switzerland.

[17] UNEP. 2011. International Year of Forests. 2011. Un.org. Retrieved on 12 December, 2016.

[18] Nelson, 2005. Chapter 3: Drivers of Ecosystem Change: Summary Chapter in Current State and Trends Assessment Millenium Ecosystem Assessment. Retrieved on 12 December, 2016.

[19] Clark, H. 2002. UNESCO and UNEP 2002 Cultural Diversity and Biodiversity for Sustainable Development, World Summit on Sustainable Development, Johannesburg. 
[20] UN, 1982. General Assembly World Charter for Nature: 48th Plenary meeting. United Nations. Retrieved on 12 December, 2016.

[21] Fein, J. 2003. Learning to care: education and compassion. Australian Journal of Environmental Education, 19: 1-13. https://doi.org/10.1017/S0814062600001427

[22] Soulé, M.E. and Wilcox, B.A. 1980. Conservation Biology: An Evolutionary-Ecological Perspective. Sinauer Associatess, Sunderland, Massachusetts.

[23] Soule, M.E. 1986. What is conservation Biology? BioScience, 35(11): 727-734.

[24] Soule, M.E. 1986. Conservation Biology: The Science of Scarcity and Diversity. Sinauer Associates, Sunderland, MA, p. 584.

[25] Hunter, M.L. 1996. Fundamentals of Conservation Biology. Blackwell Science Inc., Cambridge, Massachusetts.

[26] Groom, M.J., Meffe, G.K. and Carroll, C.R. 2006. Principles of Conservation Biology (3rd ed.). Sinauer Associates, Sunderland, MA.

[27] van Dyke, Fred. 2008. Conservation Biology: Foundations, Concepts, Applications (2nd ed.). Springer Verlag, p. 478. https://doi.org/10.1007/978-1-4020-6891-1

[28] Habitat Conservation Planning Branch. 2009. Habitat Conservation. California Department of Fish and Game. Retrieved on 7 April, 2009.

[29] Ostrom, E. 2005. In Kommers, N. and Mackie, P. (Eds.). Journalist guide to world resources 2005 World Resources Institute, pp. 1-30.

[30] UNDP,UNEP, The World Bank and World Resources Institute . 2005. The Wealth of the Poor: Managing Ecosystems to Fight Poverty Institute 2005, Chapter: 3. The board's role in governance, World Resources 2005. Retrieved on 25 July, 2011. 